\title{
Ameliorative role of a combination of chitosan, calcium, vitamins $A$ and $E$ against high fat diets-induced adverse effects in rats
}

Atef Abdel-Moneem Ali ${ }^{1 *}$, Anwar Mansour ${ }^{1}$, El-sayed Abd-elkhalik Hassanine², Amal Hamed Abdel-Razek² and Heba Ali Hassan Mahmoud ${ }^{2}$

\begin{abstract}
Background: Chitosan is a promising natural source for controlling obesity. Obese people tend to use supplementary nutrients to compensate for their deficiencies in their diets. The present study aimed to investigate the combined effect of chitosan, calcium, and vitamins A and E supplements against the adverse effects of high-fat diet consumption in rats.

Methods: Twenty-five male albino rats were assigned into five equal groups. Control rats were fed standard basal diet (SBD). Another group was fed high-fat diet (HFD) without supplements. The other three groups were fed HFD containing 0,400 , and $800 \mathrm{mg}$ of chitosan per kilogram diet, in presence of calcium and vitamins A and $\mathrm{E}$ supplements, daily for 10 weeks.

Results: As compared to controls, rats fed HFD without supplements showed significant elevations in body weight gain, feed consumption, relative weights of the heart and liver, serum levels of total cholesterol, triglycerides, low-density lipoprotein cholesterols, very low-lipoprotein triglycerides, urea, creatinine, and malondialdehyde, as well as serum activities of alanine and aspartate aminotransferases, alkaline phosphatase, and creatine kinase. Moreover, significant declines in the relative kidney weight, serum levels of high-density lipoprotein cholesterols, total proteins, albumin, globulin, calcium, vitamins A and E, erythrocyte glutathione content, and superoxide dismutase activity were recorded. Histopathological alterations were observed in rats fed HFD with or without supplements. On contrary, rats fed HFD containing chitosan and supplements showed remarkable improvement in all the studied parameters towards control values, in dose-dependent manner.
\end{abstract} Conclusion: Chitosan, calcium, and vitamins A and E attenuated the adverse effects caused by HFD intake in rats. Keywords: Biochemical variables, Biological parameters, Calcium, Fat-soluble vitamins, High-fat diet, Chitosan, Histopathology, Rats

\footnotetext{
* Correspondence: Atef@sci.cu.edu.eg

${ }^{1}$ Physiology Division, Zoology Department, Faculty of Science, Cairo

University, Giza, Egypt

Full list of author information is available at the end of the article
} 


\section{Background}

Obesity is considered one of the biggest challenges threatening public health. Obesity is mainly produced by an imbalance between the input of calories and the energy expenditure (Delamater, Pulgaron, \& Daigre, 2013). Such imbalance results in an abnormal accumulation of fats in non-adipose tissues such as the muscles, liver, kidney, and heart (Bahreini et al., 2013 and Snel et al., 2012). High-fat diet (HFD) contributes largely to obesity prevalence (Myles, 2014). The quality of life is adversely affected by obesity as being related to the incidence of several disorders such as hypertension, diabetes, osteoarthritis, and cardiovascular diseases (Boden, 2011). Therefore, more attention of scientific community was initiated to solve this serious problem. Several medications were approved for obesity controlling. However, most of these drugs have adverse side effects, expensive, and take long time to produce their effects (Mhurchu, Dunshea-Mooij, Bennett, \& Rodgers, 2005).

Chitosan is a natural polysaccharide that is produced from chitin by N-deacetylation (Anraku et al., 2018). Globally, chitin is considered one of the most plentiful natural water-insoluble polymers (Muxika, Etxabide, Uranga, Guerrero, \& De La Caba, 2017). Exoskeletons of invertebrates especially crustaceans represent the chief sources of chitin (Kumirska et al., 2010). Chitosan has cationic nature that facilitates its penetration through cellular membranes (Cheung, Ng, Wong, \& Chan, 2015). Recently, chitosan was involved in gene delivery due to its biocompatibility (Choi, Nam, \& Nah, 2016). Chitosan also has the ability to accelerate wound healing (Patrulea, Ostafe, Borchard, \& Jordan, 2015). Moreover, chitosan is effectively used in management of body weight via scavenging lipids for further excretion (Walsh, Sweeney, Bahar, \& O'Doherty, 2013). Lately, chitosan was reported to exert antioxidant properties both in vivo and in vitro (Anraku et al., 2011).

Calcium $\left(\mathrm{Ca}^{2+}\right)$ is primarily component in bone formation (Bonjour et al., 2014). In addition, $\mathrm{Ca}^{2+}$ also mediates muscle contraction, nerve signaling, vasodilation, and hormone secretion (Nobre et al., 2011). Vitamin A represents a vital micronutrient that is mainly found in carrot, mangos, liver, and eggs (Eastep \& Chen, 2015). Vitamin A and retinoids are responsible for regulation of growth, reproduction, and epithelial tissue maintenance and repair in mammals (Eastep \& Chen, 2015). Vitamin E is a general term that describes a group of fat-soluble vitamins (tocopherols and tocotrienols) with remarkable antioxidant properties (Niki \& Traber, 2012). Vitamin E represents a major component of the endogenous antioxidant system that is obtained mainly from vegetable oils (Rizvi et al., 2014). The high lipophilicity of vitamin $E$ allows its storage in adipose tissue and consequently, enhances its bioavailability (Zingg, 2007).
Obese people usually tend to use mineral and vitamin supplements to compensate for their deficiency in the unbalanced diet. To our knowledge, studies on the interaction between chitosan and other supplements are still rare (Rodrigues, Silva, \& Lacerda, 2012). Accordingly, the present work was designed to study the potential combined effects of chitosan, calcium, and vitamins A and $E$ supplements against the adverse effects induced by HFD consumption in rats.

\section{Methods \\ Experimental diet}

Two types of diets were applied in the present study. The first type was the standard basal diet (SBD) that was prepared according to the method described by Reeves, Nielsen, and Fahey Jr (1993). The second diet was the high-fat diet (HFD) that was prepared by modification of SBD by increasing the amount of lipids while decreasing the carbohydrate content (Chien, Ku, Chang, Yang, \& Chen, 2016). The chemical composition of both diets is presented in Table 1.

\section{Supplements}

Chitosan of high molecular weight $(310,000-375,000 \mathrm{Da})$, vitamin A (retinyl palmitate), and vitamin E (DL- $\alpha$-tocopherol acetate) were obtained from Sigma-Aldrich chemical company, USA. Calcium $\left(\mathrm{Ca}^{2+}\right)$ was purchased as in the form of calcium carbonate from El Nasr pharmaceutical chemical company, Egypt. The amounts of vitamin A, calcium and vitamin $\mathrm{E}$ were supplemented according to Mahassni and Al-Shaikh (2013), Nobre et al. (2011) and Shen, Tang, Huang, and Cai (2010), respectively.

\section{Animals}

Adult healthy male Sprague Dawley rats, weighing $100 \pm$ $10 \mathrm{~g}$, were purchased from VACERA vivarium, Helwan,

Table 1 The percentage of chemical constituents of the standard basal diet (SBD) and high-fat diet (HFD)

\begin{tabular}{lll}
\hline Constituent & SBD & HFD \\
\hline Cornstarch (\%) & 56.07 & 26.07 \\
Casein (\%) & 14.00 & 14.00 \\
Sucrose (\%) & 10.00 & 10.00 \\
Corn oil (\%) & 10.00 & 10.00 \\
Cellulose (\%) & 5.00 & 5.00 \\
Minerals (\%) & 3.50 & 3.50 \\
Vitamins (\%) & 1.00 & 1.00 \\
Methionine (\%) & 0.18 & 0.18 \\
Choline chloride (\%) & 0.25 & 0.25 \\
Tert-butyl hydroquinone (\%) & 0.00 & 0.00 \\
Lard (\%) & 0.00 & 30.00 \\
\hline
\end{tabular}

*Significantly differed $(P<0.05)$, as compared to the SBD 
Egypt. The rats were housed in an animal house of the Nutrition National Institute (NNI), Cairo, Egypt and maintained on standard diet and tap water for 1 week, for acclimatization, before starting the experiments.

\section{Study design}

Twenty-five male rats were divided into five groups (5 rats/group) as shown in Table 2.

\section{Sampling}

At the end of the experiment, rats were fasted for $12 \mathrm{~h}$ then were sacrificed under anesthesia using sodium pentobarbital. Blood samples were collected from the vagal vein and divided into two parts. The first part was collected in dry test tubes and allowed to stand, then were centrifuged at $3000 \mathrm{rpm}$ for $15 \mathrm{~min}$ to separate the serum. The clear serum was stored in the deep freezer at $-20^{\circ} \mathrm{C}$ for subsequent biochemical analysis. The second part was collected on EDTA and then centrifuged at $1000 \times g$ for $10 \mathrm{~min}$ at $40^{\circ} \mathrm{C}$. The resultant plasma and white buffy layer were discarded. The remaining erythrocytes were lysed in ice-cold HPLC grade water and then centrifuged at $10000 \times g$ for $15 \mathrm{~min}$ at $4{ }^{\circ} \mathrm{C}$. The supernatant erythrocyte lysate was collected and stored in a deep freezer at $-80^{\circ} \mathrm{C}$. Dissection was executed immediately after scarifying to extract the heart, kidney, and liver. The extracted organs were minced in physiological saline $(0.9 \%)$ and then dried using filter papers and weighed immediately.

\section{Biological parameters}

The amount of food consumed by each group was determined weekly throughout the experiments and then divided by the number of animals per group to estimate the average of food consumption. The starting and final weights of all the experimental rats were measured to calculate the body weight gain (BWG), after receiving diets. The relative weights of the heart, kidney, and liver

Table 2 Summarized experimental design of the study

\begin{tabular}{|c|c|c|c|c|c|}
\hline \multirow[t]{2}{*}{ Conditions } & \multicolumn{5}{|c|}{ Experimental groups ( $N=25$ rats) } \\
\hline & I & $\|$ & III & IV & $\mathrm{V}$ \\
\hline Diet type & $\mathrm{SBD}$ & HFD & & & \\
\hline Chitosan content (mg/kg diet) & 0 & 0 & 0 & 400 & 800 \\
\hline Calcium content (g/kg diet) & - & - & 10 & 10 & 10 \\
\hline Vitamin A content (mg/kg diet) & - & - & 11 & 11 & 11 \\
\hline Vitamin E content (mg/kg diet) & - & - & 350 & 350 & 350 \\
\hline Frequency & \multicolumn{5}{|l|}{ Daily } \\
\hline Duration & \multicolumn{5}{|c|}{ For 10 weeks } \\
\hline Sampling & \multicolumn{5}{|c|}{ At the end of experimental period } \\
\hline
\end{tabular}

SBD Standard basal diet; HFD high fat diet of all the experimental groups were estimated at the end of experiments.

\section{Biochemical analysis}

\section{Determination of serum lipid profile}

The levels of serum total cholesterol (TC), triglycerides (TG), and high- and low-density lipoprotein cholesterols (HDL-C \& LDL-C), were analyzed using Analyticon Biotechnologies kit, Germany, according to the techniques designated by Allain, Poon, Chan, Richmond, and Fu (1974), Nauck et al. (1997), Sullivan, Kruijswijk, West, Kohlmeier, and Katan (1985), and Wieland and Seidel (1983), respectively. The levels of very low-lipoprotein triglycerides (VLDL-TG) were computed according to the Friedewald formula: VLDL-TG $=$ TG/5.

\section{Determination of serum protein profile}

The levels of total proteins (TP) and albumin were estimated according to the pamphlet of ELiTech kit, France, according to the methods described by Bartholomew and Delaney (1964) and Doumas (1975) respectively. The levels of globulin and albumin/globulin ratio were calculated as described by Cui et al. (2015).

\section{Determination of serum aminotransferases activity}

The activities of serum alanine and aspartate aminotransferases (ALAT and ASAT) were determined according to the method stated by Schumann et al. (2002a, 2002b), using kits obtained from Stanbio Laboratory company, USA.

\section{Determination of serum alkaline phosphatase activity}

Serum alkaline phosphatase (ALP) was determined according to the manual instruction of the kit from Biosystem, Spain. The method was described by Tietz, Rinker, and Shaw (1983).

\section{Determination of serum creatine kinase activity}

The activity of creatine kinase (CK) was analyzed as described by Burtis, Ashwood, and Bruns (2012) using Spectrum kits (Cairo, Egypt).

\section{Determination of serum creatinine and urea levels}

Serum creatinine level was determined according to the manual instruction of the kit from BioMed, Egypt (Toora \& Rajagopal, 2002). Serum urea was determined according to the manual instruction of the kit from Diamond, Egypt (Tabacco, Meiattini, Moda, \& Tarli, 1979).

\section{Determination of serum total calcium levels}

The serum levels of the calcium determination test was performed according to Kessler and Wolfman (1964), using Spectrum kits (Cairo, Egypt). 


\section{Determination of serum vitamins $A$ and $E$ concentrations} The levels of vitamins $A$ and $E$ were determined in the serum of rats by aid of high-performance liquid chromatography (HPLC). The method of determination was according to Bieri, Tolliver, and Catignani (1979).

\section{Determination of lipid peroxidation biomarker and endogenous antioxidants}

Serum levels of malondialdehyde (MDA) were determined as lipid peroxidation (LPO) biomarker according to the method described by Uchiyama and Mihara (1978). The level of glutathione (GSH) and activity of superoxide dismutase (SOD) were detected in the erythrocyte as stated by Beutler (1963) and Winterbourn, Hawkins, Brian, and Carrell (1975), respectively. The serum levels of MDA as well as erythrocyte GSH content and SOD activity were estimated using Bio-diagnostic Kits (Giza, Egypt).

\section{Histological examination}

Small parts of the heart, kidney, and liver were fixed in $10 \%$ formalin for histological examination. The fixed tissues were processed for preparation of paraffin sections with thickness of $5 \mu \mathrm{m}$. These sections were then stained with hematoxylin and eosin, as described by Suvarna, Layton, and Bancroft (2018).

\section{Statistical analysis}

The present data were statistically analyzed using Statistical Package for the Social Sciences (SPSS) version 22. Kolmogorov-Smirnov tests revealed that data was normally distributed, i.e., variables were parametric (Razali \& Wah, 2011). Post hoc Duncan's test was used to show similarities in all the studied parameters among the experimental groups. Pearson's correlation coefficient was applied to correlate the studied parameters to the amount of chitosan in diet.

\section{Results}

\section{Effect on biological parameters}

The BWG, feed consumption, and relative weights of the heart, kidney, and liver of all the experimental rats, after 10 weeks of receiving the appropriate diets, were displayed in Table 3. In rats of groups II, III, and IV, BWG and feed consumption were significantly higher than in group I. Rats of group IV showed remarkable reductions in BWG and feed intake, as compared to groups II and III, but were markedly higher than in group V. In rats of groups III, IV, and $\mathrm{V}$, the chitosan amount was negatively correlated with the BWG and feed consumption. Rats of groups II and III exhibited a marked decline in the relative kidney weight, but remarkable elevations in relative weights of the heart and liver, in comparison to the other groups. Relative liver weight of group IV was noticeably higher than in group I.

Table 3 Body weight gain (BWG), feed consumption, and relative weights of the heart, kidney, and liver of all the experimental groups, at the end of the experiments

\begin{tabular}{|c|c|c|c|c|c|}
\hline \multirow[t]{2}{*}{ Variables } & \multicolumn{5}{|c|}{ Experimental groups } \\
\hline & I & $\|$ & III & IV & V \\
\hline \multirow[t]{3}{*}{ BWG (g/10 weeks) } & $24.40 \pm 0.98^{a}$ & $36.80 \pm 2.15^{c}$ & $37.60 \pm 0.51^{c}$ & $31.40 \pm 1.54^{b}$ & $25.80 \pm 0.58^{\mathrm{a}}$ \\
\hline & - & $(+50.8 \%)^{\#}$ & $(+2.2 \%)^{n}$ & $(-14.7 \%)^{n}$ & $(-29.9 \%)^{n}$ \\
\hline & & & & $r^{d}=-0.92, P<0.001$ & \\
\hline \multirow[t]{3}{*}{ Feed consumption (g/day) } & $9.43 \pm 0.35^{\mathrm{a}}$ & $12.56 \pm 0.50^{c}$ & $11.20 \pm 0.37^{c}$ & $10.88 \pm 0.32^{b}$ & $9.27 \pm 0.23^{a}$ \\
\hline & - & $(+33.2 \%)^{\#}$ & $(-10.8 \%)^{\pi}$ & $(-13.3 \%)^{n}$ & $(-26.2 \%)^{n}$ \\
\hline & & & & $r^{d}=-0.75, P<0.01$ & \\
\hline \multirow[t]{3}{*}{ Relative heart weight ( $\mathrm{g} / 100 \mathrm{~g} \mathrm{BW}$ ) } & $0.29 \pm 0.01^{\mathrm{a}}$ & $0.43 \pm 0.01^{b}$ & $0.41 \pm 0.01^{b}$ & $0.27 \pm 0.01^{\mathrm{a}}$ & $0.26 \pm 0.01^{\mathrm{a}}$ \\
\hline & - & $(+48.3 \%)^{\#}$ & $(-4.7 \%)^{n}$ & $(-37.2 \%)^{n}$ & $(-39.5 \%)^{n}$ \\
\hline & & & & $r^{d}=-0.80, P<0.001$ & \\
\hline \multirow[t]{3}{*}{ Relative kidney weight ( $\mathrm{g} / 100 \mathrm{~g} \mathrm{BW}$ ) } & $0.82 \pm 0.02^{b}$ & $0.67 \pm 0.03^{\mathrm{a}}$ & $0.66 \pm 0.01^{a}$ & $0.80 \pm 0.06^{b}$ & $0.80 \pm 0.02^{b}$ \\
\hline & - & $(-18.3 \%)^{\#}$ & $(-1.5 \%)^{n}$ & $(+19.4 \%)^{\natural}$ & $(+19.4 \%)^{n}$ \\
\hline & & & & $r^{d}=+0.55, P<0.05$ & \\
\hline \multirow[t]{3}{*}{ Relative liver weight (g/100 g BW) } & $2.49 \pm 0.11^{\mathrm{a}}$ & $3.20 \pm 0.06^{c}$ & $3.16 \pm 0.08^{c}$ & $2.88 \pm 0.08^{b}$ & $2.65 \pm 0.04^{\mathrm{ab}}$ \\
\hline & - & $(+28.5 \%)^{\#}$ & $(-1.3 \%)^{n}$ & $(-10.0 \%)^{n}$ & $(-17.2 \%)^{\natural}$ \\
\hline & & & & $r^{d}=-0.83, P<0.001$ & \\
\hline
\end{tabular}

Data is displayed as mean \pm standard error of mean. $P<0.05, P<0.01$, and $P<0.001$ represent significant correlations. In the same raw, values marked with similar superscript letters are insignificantly different $(P>0.05)$, whereas those marked with different ones are statistically different $(P<0.05)$

$r^{d}$ : correlation coefficient between the studied variables and the administered doses of chitosan, I: control rats, II: rats fed HFD without supplements, III: rats fed HFD + supplements, IV: rats fed HFD + supplements + $400 \mathrm{mg}$ chitosan and V: rats fed HFD + supplements + $800 \mathrm{mg}$ chitosan

\#Percent of change in comparison to the group I

"Percent of change in comparison to the group ॥ 


\section{Effect on lipid profile in serum}

In Table 4, the levels of TC, TG, HDL-C, LDL-C, and VLDL-TG in the serum of all the experimental groups were recorded. Rats of groups II and III exhibited marked elevations in serum levels of TC, TG, LDL-C, and VLDL-TG, whereas a remarkable decline in HDL-C levels, as compared to group I. In comparison to groups II and III, rats of groups IV and V showed significant reductions in the serum levels of TC, TG, LDL-C, and VLDL-TG, whereas a remarkable elevation in HDL-C levels towards the control values.

\section{Effect on protein profile in serum}

The concentrations of TP, albumin, globulin, and albu$\mathrm{min} /$ globulin ratio of all groups were clarified in Table 5 . In rats of groups II and III, serum levels of most protein variables were markedly lower than in groups I, IV, and $\mathrm{V}$. By increasing the amount of chitosan in HFD containing supplements, serum levels of all protein variables were significantly elevated towards the normal values of controls.

\section{Effect on activities of aminotransferases, alkaline} phosphatase, and creatine kinase, as well as levels of creatinine and urea in serum

Table 6 displayed the serum activities of ALAT, ASAT, ALP, and CK, as well as the serum levels of creatinine and urea of all rats. Rats of groups II, III, IV, and V exhibited marked elevations in serum activities of ALAT, ASAT, and ALP, in comparison to group I. The serum activities of ALAT, ASAT, and ALP of group IV were significantly higher than in group $\mathrm{V}$, whereas remarkably lower than in groups II and III. Among all the experimental groups, serum activity of CK and serum levels of creatinine and urea were similar except for marked elevations in groups II and III.

\section{Effect on serum levels of calcium, and vitamins $A$ and $E$}

The serum levels of calcium and vitamins $A$ and $E$ of all groups were shown in Table 7 . In rats of group II, serum levels of calcium, and vitamins $\mathrm{A}$ and $\mathrm{E}$ were significantly depleted, as compared to the other groups. Group III showed marked elevations in serum levels of calcium and vitamins $\mathrm{A}$ and $\mathrm{E}$, in comparison to the rest of groups. In rats of group IV, serum levels of calcium and vitamins $A$ and $E$ were significantly greater than in group V. Rats of groups IV and V revealed remarkable elevations in vitamins A and E levels in serum, as compared to groups I and II.

\section{Effect on serum levels of malondialdehyde and erythrocyte glutathione content and superoxide dismutase activity} The serum MDA level as well as erythrocyte GSH content and SOD activity of all groups were shown in

Table 4 The levels of total cholesterol (TC), triglycerides (TG), high- and low-density lipoprotein cholesterols (HDL-C \& LDL-C) and very low-density lipoprotein triglyceride (VLDL-TG) in serum of all the experimental groups, at the end of the experiments

\begin{tabular}{|c|c|c|c|c|c|}
\hline \multirow[t]{2}{*}{ Variables } & \multicolumn{5}{|c|}{ Experimental groups } \\
\hline & I & $\|$ & III & IV & V \\
\hline \multirow[t]{3}{*}{$\overline{\mathrm{TC}}$ levels (mg/dL) } & $92.20 \pm 1.24^{a}$ & $165.80 \pm 2.78^{d}$ & $160.60 \pm 2.78^{d}$ & $124.00 \pm 0.89^{c}$ & $111.60 \pm 0.81^{b}$ \\
\hline & - & $(+79.8 \%)^{\#}$ & $(-3.1 \%)^{n}$ & $(-25.2 \%)^{n}$ & $(-32.7 \%)^{n}$ \\
\hline & & & & $r^{d}=-0.94, P<0.001$ & \\
\hline \multirow[t]{3}{*}{ TG levels (mg/dL) } & $75.20 \pm 0.49^{a}$ & $175.40 \pm 4.23^{d}$ & $173.60 \pm 4.01^{d}$ & $99.80 \pm 1.07^{c}$ & $88.20 \pm 2.15^{b}$ \\
\hline & - & $(+133.2 \%)^{\#}$ & $(-1.0 \%)^{q}$ & $(-43.1 \%)^{n}$ & $(-49.9 \%)^{n}$ \\
\hline & & & & $r^{d}=-0.91, P<0.001$ & \\
\hline \multirow[t]{3}{*}{ HDL-C levels (mg/dL) } & $44.80 \pm 1.39^{b}$ & $23.60 \pm 1.47^{\mathrm{a}}$ & $24.60 \pm 1.50^{\mathrm{a}}$ & $46.20 \pm 1.81^{b}$ & $46.00 \pm 1.87^{b}$ \\
\hline & - & $(-47.3 \%)^{\#}$ & $(+4.2 \%)^{\natural}$ & $(+95.8 \%)^{\natural}$ & $(+94.9 \%)^{\natural}$ \\
\hline & & & & $r^{d}=+0.81, P<0.001$ & \\
\hline \multirow[t]{3}{*}{ LDL-C levels (mg/dL) } & $30.40 \pm 2.26^{a}$ & $107.04 \pm 2.53^{d}$ & $104.06 \pm 1.72^{d}$ & $57.36 \pm 2.18^{c}$ & $48.32 \pm 0.75^{b}$ \\
\hline & - & $(+252 \%)^{\#}$ & $(-2.3 \%)^{\natural}$ & $(-46.4 \%)^{\natural}$ & $(-54.9 \%)^{\natural}$ \\
\hline & & & & $r^{d}=-0.92, P<0.001$ & \\
\hline \multirow[t]{3}{*}{ VLDL-TG levels (mg/dL) } & $15.00 \pm 0.06^{\mathrm{a}}$ & $35.08 \pm 1.71^{c}$ & $34.40 \pm 1.21^{c}$ & $20.06 \pm 0.04^{b}$ & $17.44 \pm 0.41^{\mathrm{a}}$ \\
\hline & - & $(+133 \%)^{\#}$ & $(-1.9 \%)^{q}$ & $(-42.8 \%)^{9}$ & $(-50.3 \%)^{q}$ \\
\hline & & & & $r^{d}=-0.91, P<0.001$ & \\
\hline
\end{tabular}

Data is displayed as mean \pm standard error of mean. $P<0.001$ represents significant correlation. In the same raw, values marked with similar superscript letters are insignificantly different $(P>0.05)$, whereas those marked with different ones are statistically different $(P<0.05)$

$r^{d}$ : correlation coefficient between the studied variables and the administered doses of chitosan (0, 400 , and $\left.800 \mathrm{mg}\right)$, I: control rats, II: rats fed HFD without supplements, III: rats fed HFD + supplements, IV: rats fed HFD + supplements +400 mg chitosan and V: rats fed HFD + supplements + 800 mg chitosan "Percent of change in comparison to the group I

"Percent of change in comparison to the group II 
Table 5 The levels of total proteins (TP), albumin, globulin, and albumin/globulin ratio in the serum of all the experimental groups, at the end of the experiments

\begin{tabular}{|c|c|c|c|c|c|}
\hline \multirow[t]{2}{*}{ Variables } & \multicolumn{5}{|c|}{ Experimental groups } \\
\hline & I & II & III & IV & V \\
\hline \multirow[t]{3}{*}{ TP levels (g/dL) } & $6.30 \pm 0.21^{d}$ & $3.08 \pm 0.12^{a}$ & $3.04 \pm 0.10^{a}$ & $4.04 \pm 0.07^{b}$ & $4.48 \pm 0.02^{c}$ \\
\hline & - & $(-51.1 \%)^{\#}$ & $(-1.3 \%)^{n}$ & $(+31.2 \%)^{\natural}$ & $(+45.5 \%)^{n}$ \\
\hline & & & & $=+0.95, P<0.001$ & \\
\hline \multirow[t]{3}{*}{ Albumin levels (g/dL) } & $4.18 \pm 0.19^{d}$ & $1.94 \pm 0.11^{\mathrm{a}}$ & $1.96 \pm 0.09^{\mathrm{a}}$ & $2.76 \pm 0.14^{b}$ & $3.26 \pm 0.09^{c}$ \\
\hline & - & $(-53.6 \%)^{\#}$ & $(+1.0 \%)^{\natural}$ & $(+42.3 \%)^{9}$ & $(+68.0 \%)^{\natural}$ \\
\hline & & & & $=+0.92, P<0.001$ & \\
\hline \multirow[t]{3}{*}{ Globulin levels (g/dL) } & $2.12 \pm 0.04^{d}$ & $1.14 \pm 0.04^{\mathrm{a}}$ & $1.21 \pm 0.07^{\mathrm{a}}$ & $1.28 \pm 0.04^{b}$ & $1.54 \pm 0.02^{c}$ \\
\hline & - & $(-46.2 \%)^{\#}$ & $(+6.1 \%)^{n}$ & $(+12.3 \%)^{n}$ & $(+35.1 \%)^{\natural}$ \\
\hline & & & & $=+0.78, P<0.01$ & \\
\hline \multirow[t]{3}{*}{ Albumin/globulin ratio (\%) } & $1.97 \pm 0.09^{\mathrm{ab}}$ & $1.70 \pm 0.10^{\mathrm{a}}$ & $1.73 \pm 0.09^{\mathrm{a}}$ & $2.16 \pm 0.12^{b}$ & $2.12 \pm 0.07^{b}$ \\
\hline & - & $(-13.7 \%)^{\#}$ & $(+1.8 \%)^{\natural}$ & $(+27.1 \%)^{9}$ & $(+24.7 \%)^{\natural}$ \\
\hline & & & & $=+0.59, P<0.05$ & \\
\hline
\end{tabular}

Data is displayed as mean \pm standard error of mean. $P<0.05, P<0.01$, and $P<0.001$ represent significant correlations. In the same raw, values marked with similar superscript letters are insignificantly different $(P>0.05)$, whereas those marked with different ones are significantly different $(P<0.05)$

$r^{\mathrm{d}}$ : correlation coefficient between the studied variables and the administered doses of chitosan (0, 400, and $\left.800 \mathrm{mg}\right)$, I: control rats, II: rats fed HFD without supplements, III: rats fed HFD + supplements, IV: rats fed HFD + supplements + $400 \mathrm{mg}$ chitosan and V: rats fed HFD + supplements + 800 mg chitosan

"Percent of change in comparison to the group I

"Percent of change in comparison to the group II

Table 6 The activities of alanine and aspartate aminotransferases (ASAT and ALAT), alkaline phosphatase (ALP), and creatine kinase (CK) as well as levels of creatinine and urea in the serum of all the experimental groups, at the end of the experiments

\begin{tabular}{|c|c|c|c|c|c|}
\hline \multirow[t]{2}{*}{ Variables } & \multicolumn{5}{|c|}{ Experimental groups } \\
\hline & I & $\|$ & III & IV & V \\
\hline \multirow[t]{3}{*}{ ALAT activity (U/L) } & $27.60 \pm 0.51^{a}$ & $63.80 \pm 1.43^{d}$ & $61.40 \pm 1.88^{d}$ & $54.80 \pm 1.39^{c}$ & $44.00 \pm 1.41^{b}$ \\
\hline & - & $(+131 \%)^{\#}$ & $(-3.8 \%)^{n}$ & $(-14.1 \%)^{n}$ & $(-31.0 \%)^{n}$ \\
\hline & & & & $r^{d}=-0.90, P<0.001$ & \\
\hline \multirow[t]{3}{*}{ ASAT activity (U/L) } & $84.00 \pm 2.23^{\mathrm{a}}$ & $195.60 \pm 4.37^{d}$ & $189.80 \pm 5.29^{d}$ & $134.40 \pm 4.84^{c}$ & $120.20 \pm 1.74^{b}$ \\
\hline & - & $(+133 \%)^{\#}$ & $(-3.0 \%)^{n}$ & $(-31.3 \%)^{n}$ & $(-38.5 \%)^{n}$ \\
\hline & & & & $r^{d}=-0.91, P<0.001$ & \\
\hline \multirow[t]{3}{*}{ ALP activity (U/L) } & $117.60 \pm 2.16^{\mathrm{a}}$ & $286.60 \pm 18.10^{d}$ & $278.00 \pm 12.41^{d}$ & $179.60 \pm 2.93^{c}$ & $153.80 \pm 2.91^{b}$ \\
\hline & - & $(+144 \%)^{\#}$ & $(-3.0 \%)^{\pi}$ & $(-37.3 \%)^{n}$ & $(-46.3 \%)^{n}$ \\
\hline & & & & $r^{d}=-0.91, P<0.001$ & \\
\hline \multirow[t]{3}{*}{ CK activity (U/L) } & $922.80 \pm 11.97^{\mathrm{a}}$ & $1153.20 \pm 13.28^{b}$ & $1106.00 \pm 32.19^{b}$ & $935.20 \pm 41.94^{\mathrm{a}}$ & $913.60 \pm 40.63^{a}$ \\
\hline & - & $(+16.2 \%)^{\#}$ & $(-4.1 \%)^{\natural}$ & $(-18.9 \%)^{9}$ & $(-20.8 \%)^{n}$ \\
\hline & & & & $r^{d}=-0.68, P<0.01$ & \\
\hline \multirow[t]{3}{*}{ Creatinine level (mg/dL) } & $0.66 \pm 0.04^{a}$ & $0.96 \pm 0.05^{b}$ & $0.89 \pm 0.03^{b}$ & $0.66 \pm 0.05^{\mathrm{a}}$ & $0.64 \pm 0.02^{\mathrm{a}}$ \\
\hline & - & $(+45.5 \%)^{\#}$ & $(-7.1 \%)^{n}$ & $(-31.3 \%)^{q}$ & $(-33.3 \%)^{n}$ \\
\hline & & & & $r^{d}=-0.75, P<0.001$ & \\
\hline \multirow[t]{3}{*}{ Urea level (mg/dL) } & $33.40 \pm 2.16^{a}$ & $58.40 \pm 1.50^{b}$ & $54.80 \pm 1.39^{b}$ & $37.20 \pm 1.62^{\mathrm{a}}$ & $37.40 \pm 0.87^{a}$ \\
\hline & - & $(+74.9 \%)^{\#}$ & $(-6.2 \%)^{9}$ & $(-36.3 \%)^{n}$ & $(-36.0 \%)^{n}$ \\
\hline & & & & $r^{\mathrm{d}}=-0.81, P<0.001$ & \\
\hline
\end{tabular}

Data is displayed as mean \pm standard error of mean. $P<0.01$ and $P<0.001$ represent significant correlations. In the same raw, values marked with similar superscript letters are insignificantly different $(P>0.05)$, whereas those marked with different ones are significantly different $(P<0.05)$

$r^{d}$ : correlation coefficient between the studied variables and the administered doses of chitosan (0,400, and $\left.800 \mathrm{mg}\right)$, I: control rats, II: rats fed HFD without supplements, III: rats fed HFD + supplements, IV: rats fed HFD + supplements + 400 mg chitosan and V: rats fed HFD + supplements + 800 mg chitosan "Percent of change in comparison to the group I

"Percent of change in comparison to the group II 
Table 7 The serum levels of calcium, vitamins A and E, and malondialdehyde (MDA) as well as erythrocyte content of glutathione (GSH) and activity of Superoxide dismutase (SOD) of all the experimental groups, at the end of the experiments

\begin{tabular}{|c|c|c|c|c|c|}
\hline \multirow[t]{2}{*}{ Variables } & \multicolumn{5}{|c|}{ Experimental groups } \\
\hline & I & $\|$ & III & IV & V \\
\hline \multirow[t]{3}{*}{ Calcium levels (mg/dL) } & $10.24 \pm 0.16^{\mathrm{bc}}$ & $8.58 \pm 0.15^{\mathrm{a}}$ & $12.38 \pm 0.14^{d}$ & $10.58 \pm 0.19^{c}$ & $9.92 \pm 0.09^{b}$ \\
\hline & - & $(-16.2 \%)^{\#}$ & $(+44.3 \%)^{n}$ & $(+23.3 \%)^{\natural}$ & $(+15.6 \%)^{n}$ \\
\hline & & & & $r^{d}=-0.93, P<0.001$ & \\
\hline \multirow[t]{3}{*}{ Vitamin A levels ( $\mu \mathrm{g} / \mathrm{dL})$} & $35.93 \pm 1.20^{b}$ & $24.62 \pm 0.91^{\mathrm{a}}$ & $65.22 \pm 3.81^{e}$ & $52.78 \pm 1.75^{\mathrm{d}}$ & $39.08 \pm 0.87^{c}$ \\
\hline & - & $(-31.5 \%)^{\#}$ & $(+165 \%)^{n}$ & $(+114 \%)^{\natural}$ & $(+58.7 \%)^{\natural}$ \\
\hline & & & & $r^{d}=-0.91, P<0.001$ & \\
\hline \multirow[t]{3}{*}{ Vitamin E levels ( $\mu \mathrm{g} / \mathrm{dL}$ ) } & $18.03 \pm 0.32^{\mathrm{b}}$ & $13.31 \pm 0.71^{\mathrm{a}}$ & $62.78 \pm 0.78^{\mathrm{e}}$ & $49.74 \pm 0.55^{d}$ & $46.20 \pm 0.49^{c}$ \\
\hline & - & $(-26.2 \%)^{\#}$ & $(+372 \%)^{\natural}$ & $(+274 \%)^{\pi}$ & $(+247 \%)^{\pi}$ \\
\hline & & & & $r^{d}=-0.94, P<0.001$ & \\
\hline \multirow[t]{3}{*}{ MDA levels (nmol/mL) } & $0.36 \pm 0.02^{a}$ & $1.39 \pm 0.18^{c}$ & $1.34 \pm 0.15^{c}$ & $0.73 \pm 0.02^{b}$ & $0.38 \pm 0.02^{a}$ \\
\hline & - & $(+286 \%)^{\#}$ & $(-3.6 \%)^{4}$ & $(-47.5 \%)^{9}$ & $(-72.7 \%)^{n}$ \\
\hline & & & & $r^{d}=-0.91, P<0.001$ & \\
\hline \multirow[t]{3}{*}{ GSH content (mg/dL) } & $27.37 \pm 0.66^{b}$ & $15.16 \pm 1.04^{\mathrm{a}}$ & $15.40 \pm 1.12^{\mathrm{a}}$ & $25.89 \pm 1.71^{\mathrm{b}}$ & $27.28 \pm 0.83^{b}$ \\
\hline & - & $(-44.9 \%)^{\#}$ & $(+1.6 \%)^{n}$ & $(+70.8 \%)^{9}$ & $(+79.9 \%)^{n}$ \\
\hline & & & & $r^{d}=+0.83, P<0.001$ & \\
\hline \multirow[t]{3}{*}{ SOD activity (U/L) } & $363.20 \pm 5.70^{b}$ & $264.43 \pm 7.87^{\mathrm{a}}$ & $266.40 \pm 8.18^{\mathrm{a}}$ & $346.63 \pm 24.50^{b}$ & $342.81 \pm 9.38^{b}$ \\
\hline & - & $(-27.2 \%)^{\#}$ & $(+0.7 \%)^{\natural}$ & $(+31.1 \%)^{\natural}$ & $(+29.6 \%)^{n}$ \\
\hline & & & & $r^{d}=+0.64, P<0.05$ & \\
\hline
\end{tabular}

Data is displayed as mean \pm standard error of mean. $P<0.05$ and $P<0.001$ represent significant correlations. In the same raw, values marked with similar superscript letters are insignificantly different $(P>0.05)$, whereas those marked with different ones are statistically different $(P<0.05)$

$r^{\mathrm{d}}$ : correlation coefficient between the studied variables and the administered doses of chitosan, I: control rats, II: rats fed HFD without supplements, III: rats fed HFD + supplements, IV: rats fed HFD + supplements + $400 \mathrm{mg}$ chitosan and V: rats fed HFD + supplements + 800 mg chitosan

"Percent of change in comparison to the group I

"Percent of change in comparison to the group II

Table 7. In rats of groups II and III, significant elevations in MDA levels in serum were reported in association with marked depletions in GSH content and SOD activity, as compared to groups I, IV, and V. Rats of groups IV and $\mathrm{V}$ showed a marked decline in MDA levels in serum, with increasing chitosan content in HFD. In addition, the GSH levels and SOD activity of groups IV and $\mathrm{V}$ were returned to the normal levels of group I.

\section{Histological investigations}

In the present study, no obvious lesions were observed in the heart and renal tissues of all groups except for myocardial blood vessel congestion (Fig. 1) and epithelial lining necrosis of renal tubules (Fig. 2) of groups II and III. In Fig. 3, the hepatic tissues of groups II, III, and IV exhibited fat accumulation (steatosis) in hepatocytes. In the liver tissue of group V, no marked lesions were detected except for slight vacuolation.

\section{Discussion}

In the present study, HFD was applied for two reasons. The first one was to enhance the absorption of fat soluble vitamins A and E. Secondly, this was an attempt to induce obesity in rats. As expected, in the current work, rats of groups II and III showed a significant elevation in their BWG, as compared to group I. This can be linked to the reported increase in feed consumption rates by these groups. It is noteworthy that fatty diets are characterized by high palatability that enhances their uptake (Melhorn et al., 2010). In addition, HFD can increase size and number of adipose cells (Melhorn et al., 2010), leading to increased tissue weight, as confirmed by the recorded elevations in the relative weights of the liver and heart of groups II and III, in the present data. Such fluctuations in relative organ weights reflect an induction of adverse reactions (Sayed, Ali, \& Mohamed, 2018). In the present study, histological examination of the hepatic tissue revealed abnormal fat deposition of groups II and III. Rats fed HFD without supplements showed significant reduction in the levels of serum calcium and vitamins $\mathrm{A}$ and $\mathrm{E}$. The reduced calcium levels in serum may be linked to the documented obesity-associated vitamin D deficiency that subsequently can alter calcium absorption from the intestine 

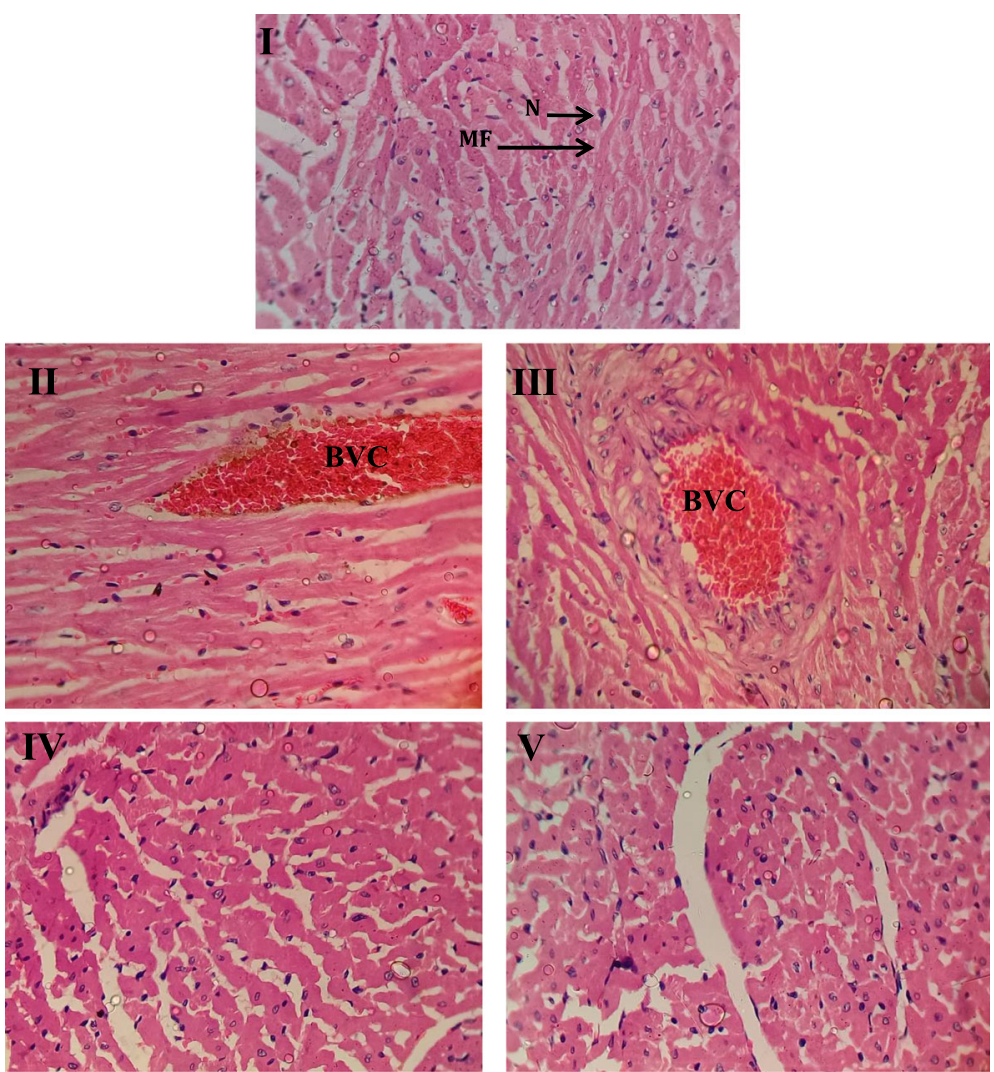

Fig. 1 Histological examination of the heart tissue of all experimental rats, at the end of experiments. I: Control rats, Il: rats fed HFD without supplements, III: rats fed HFD + supplements, IV: rats fed HFD + supplements $+400 \mathrm{mg}$ chitosan and V: rats fed HFD + supplements + 800mg chitosan. BVC: blood vessel congestion, MF: myocardial fiber and N: nucleus. Haematoxylin \& Eosin, X200

(Eastep \& Chen, 2015 and Frommelt et al., 2014). However, the reported decrease in serum levels of vitamins A and $\mathrm{E}$ may be explained by continuous displacement of fat soluble vitamins from the blood to the adipose tissue in presence of high amount of dietary fats (Sohet et al., 2009). The observed depletion in serum levels of calcium can modulate calcium-sensing receptor causing suppression of certain enzymes required for lipolysis in adipose tissue (He et al., 2011), leading to an enhanced fat deposition. Abnormal fat accumulation can induce secretion of tumor necrosis factor-alpha (TNF- $\alpha$ ) (Fonseca-Alaniz, Takada, Alonso-Vale, \& Lima, 2007). TNF- $\alpha$ cytokine can boost lipid synthesis in the liver and reactive oxygen species (ROS) production leading to induction of lipid peroxidation (LPO) (Marseglia et al., 2015). This was ensured by the reported elevations in MDA serum levels and reduced levels of GSH and activity of SOD. These findings were accompanied by significant increases of ASAT, ALAT, and ALP activities of groups II and III reflecting that hepatic functions of those rats were harmfully affected. Similarly, Haggag, Elsanhoty, and Ramadan (2014) reported that high dietary fats and oils can expressively surge LPO and can increase tissue vulnerability to injury by ROS. The reported elevation in relative heart weight of groups II and III was associated with remarkable elevations in CK activity which reflects myocardial injury (Mythili \& Malathi, 2015). This was manifested by the observed congestion of the blood vessels of the heart of these groups. In the present study, rats of group III showed remarkable elevations in the serum levels of calcium and vitamins $\mathrm{A}$ and $\mathrm{E}$. It was documented that an excess of vitamin A can cause oxidative damage through protein thiol oxidation in tissues of rats (Cha, Yu, \& Seo, 2016). This was confirmed by the increased levels of MDA in rats of group III. This could be due to the increased absorption of fat-soluble vitamins associated with high-fat diet intake. The reported decline in relative kidney weight of rats of groups II and III can be attributed to the observed necrosis in renal tubules. These findings can explain the increased levels of urea and creatinine indicating occurrence of renal dysfunction. Consequently, serum protein profile of rats of groups II and III were depleted due to leakage of albumin and amino acids from the damaged renal tubules. 


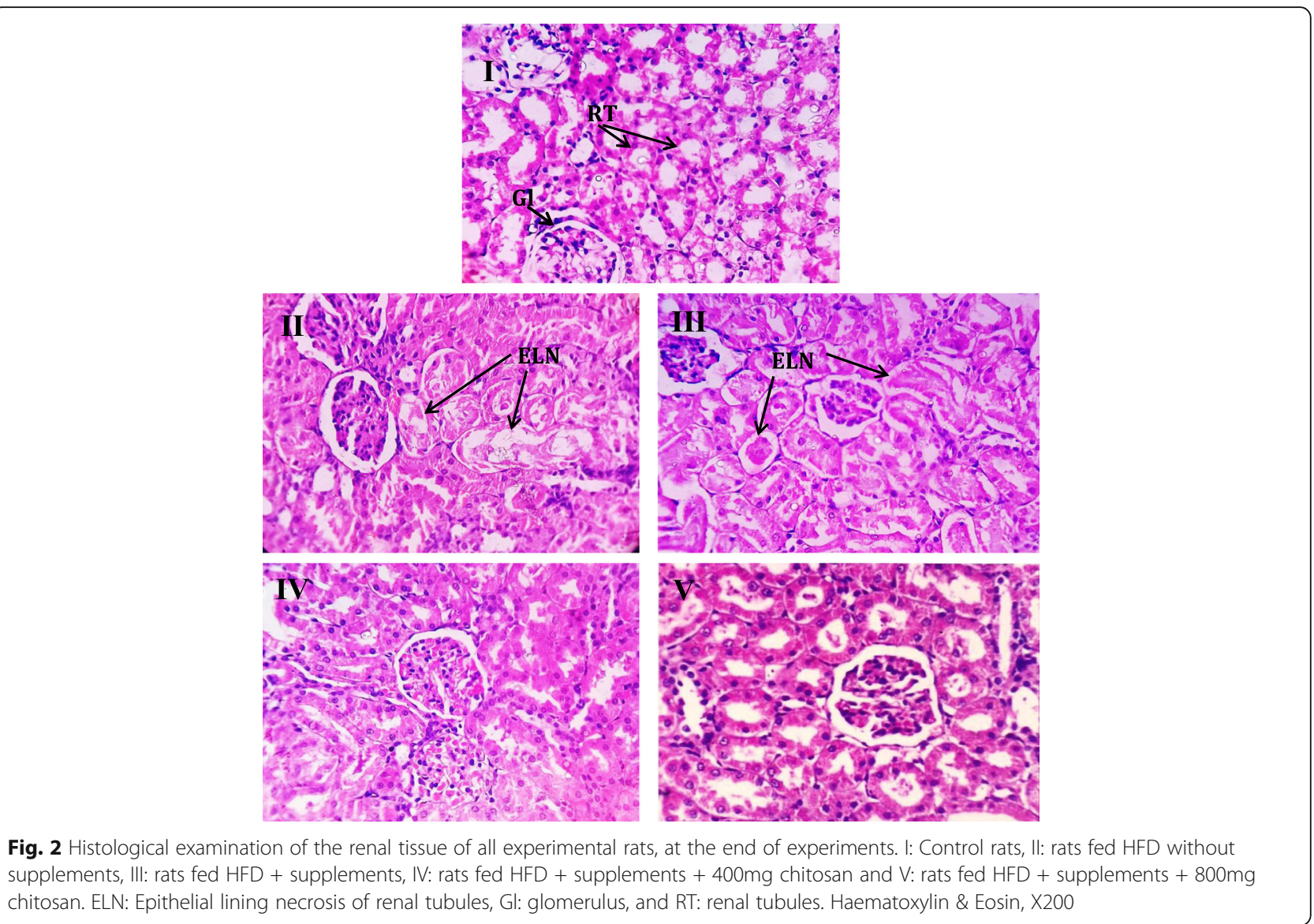

On the other hand, rats fed HFD containing supplements in addition to chitosan showed significant reductions in the average BWG and feed intake, as compared to those of groups II and III, in a dose-dependent manner. This can be linked to the reported reduction in most lipid variables after application of chitosan to the HFD, in the present study. As by increasing the chitosan content of HFD, in presence of calcium and vitamin supplements, significant reductions were recorded in the levels of all lipid variables in serum, except for marked elevations in HDL-C. This can be attributed to the ability of chitosan to bind lipids in the intestine impeding their absorption (Anraku et al., 2014). Moreover, the increased levels of HDL-C can enhance lipid transport to the liver for further elimination with bile acids (Abdel-Ghaffar, Ali, \& Soliman, 2018). Thus, chitosan in association with calcium and vitamins $\mathrm{A}$ and $\mathrm{E}$ can render the occurrence of hyperlipidemia associated obesity. In the present data, serum levels of TP, albumin, and globulin of groups IV and V were significantly elevated, as compared to groups II and III, towards the control. This can be linked to the recorded normal levels of creatinine and urea in serum of groups IV and V, reflecting the return normal renal functions and consequently, the stoppage of protein leakage from the renal tubules. In addition, chitosan can protect proteins from denaturation and oxidation (Kerch, 2015). Furthermore, this may be explained on basis of reduced oxidative stress, as manifested by the recorded reduction in the MDA levels as well as the enhanced levels of GSH and activity of SOD. This also can explain the observed marked inhibitions in the serum activities of ASAT, ALAT, ALP, and CK, with increasing the dose of chitosan in HFD. These findings could be ascribed to the antioxidant activities of chitosan (Wang et al., 2018) and vitamin E (Rizvi et al., 2014) that improved protection of liver and heart against the adverse effects of fat accumulation. This can be also attributed to the above mentioned ability of chitosan to eliminate fats. This was manifested by the reduced histopathological alterations in all the studied organs of rats fed HFD containing supplements and chitosan, as compared to the groups II and III, in the present study.

\section{Conclusion}

In rats fed HFD without supplements, significant alterations were recorded in all the studied biological, biochemical parameters, and histological examinations. By inclusion of supplements with HFD without chitosan, 


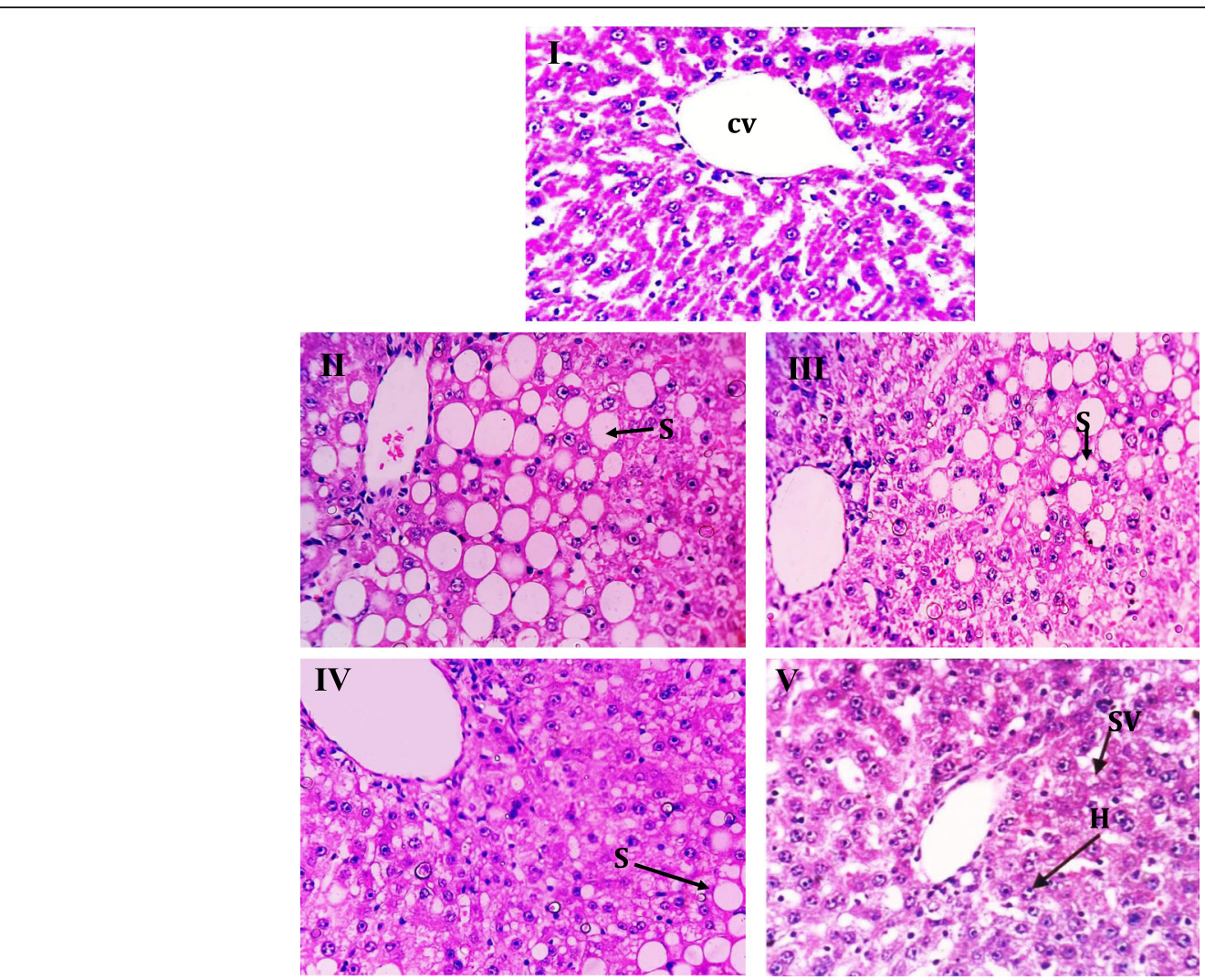

Fig. 3 Histological examination of the hepatic tissue of all experimental rats, at the end of experiments. I: Control rats, II: rats fed HFD without supplements, III: rats fed HFD + supplements, IV: rats fed HFD + supplements + 400mg chitosan and V: rats fed HFD + supplements + 800mg chitosan. CV: central vein, H: hepatocyte, S: steatosis (fat accumulation), and SV: slight vacuolation. Haematoxylin \& Eosin, X 200

marked disturbances in most of the studied variables, but remarkable elevations in serum levels of calcium and vitamins $\mathrm{A}$ and $\mathrm{E}$ were observed. However, by increasing chitosan amount in HFD containing supplements, substantial alleviations of all the studied parameters were reported, in dose-dependent manner.

\footnotetext{
Abbreviations

ALAT: Alanine aminotransferase; ALP: Alkaline phosphatase; ASAT: Aspartate aminotransferase; BVC: Blood vessel congestion; BWG: Body weight gain; CV: Central vein; ELN: Epithelial lining necrosis; Gl: Glomerulus; GSH: Glutathione; H: Hepatocytes; HDL-C: High-density lipoprotein cholesterol; HFD: High-fat diet; LDL-C: Low-density lipoprotein cholesterol; LPO: Lipid peroxidation; MDA: Malondialdehyde; MF: Myocardial fiber; N: Nucleus; RT: Renal tubules; S: Steatosis; SBD: Standard basal diet; SOD: Superoxide dismutase; SV: Slight vacuolation; TC: Total cholesterol; TG: Triglycerides; TP: Total proteins; VLDL-TG: Very low-density lipoprotein triglycerides
}

\section{Acknowledgements}

Authors acknowledge Prof. Dr. Mohamed Marzok Mohamed, professor of animal physiology for his helpful assistance in making the experimental design for this study.

\section{Funding}

No funding was provided.

\section{Authors' contributions}

AAA shared in study designing and carried out the statistical analysis of data and manuscript writing. AM and EAH are responsible for study designing and manuscript editing. AHA-R shared in study designing and carried out the biochemical analysis. HAHM is responsible for animal handling and experimental procedures. All authors read and approved the final manuscript.

Ethics approval and consent to participate

The protocol of the present study was approved by the ethical committee of the Nutrition National Institute at December 2015. The animal handling was done according to the standard international guidelines.

\section{Consent for publication}

The data provided here is original.

Competing interests

The authors declare that they have no competing interests.

\section{Publisher's Note}

Springer Nature remains neutral with regard to jurisdictional claims in published maps and institutional affiliations.

\section{Author details}

${ }^{1}$ Physiology Division, Zoology Department, Faculty of Science, Cairo University, Giza, Egypt. ${ }^{2}$ Biochemistry and Nutritional Metabolism Department, National Institute of Nutrition, Giza, Egypt. 
Received: 27 December 2018 Accepted: 20 January 2019

\section{Published online: 14 February 2019}

\section{References}

Abdel-Ghaffar, O., Ali, A. A. M., \& Soliman, S. A. M. (2018). Protective effect of Naringenin against isoniazid-induced adverse reactions in rats. International Journal of Pharmacology, 14(5), 667-680.

Allain, C. C., Poon, L. S., Chan, C. S., Richmond, W. F. P. C., \& Fu, P. C. (1974). Enzymatic determination of total serum cholesterol. Clinical Chemistry, 20(4), 470-475.

Anraku, M., Fujii, T., Kondo, Y., Kojima, E., Hata, T., Tabuchi, N., ... Maruyama, T. (2011). Antioxidant properties of high molecular weight dietary chitosan in vitro and in vivo. Carbohydrate Polymers, 83(2), 501-505.

Anraku, M., Gebicki, J. M., lohara, D., Tomida, H., Uekama, K., Maruyama, T., ... Otagiri, M. (2018). Antioxidant activities of chitosans and its derivatives in in vitro and in vivo studies. Carbohydrate Polymers, 199, 141-149.

Anraku, M., Tanaka, M., Hiraga, A., Nagumo, K., Imafuku, T., Maezaki, Y., ... Maruyama, T. (2014). Effects of chitosan on oxidative stress and related factors in hemodialysis patients. Carbohydrate Polymers, 112, 152-157.

Bahreini, N., Noor, M. I., Koon, P. B., Talib, R. A., Lubis, S. H., Dashti, M. G., Esmaillzadeh, A. (2013). Weight status among Iranian adolescents: Comparison of four different criteria. Journal of Research in Medical Sciences, 18(8), 641-646

Bartholomew, R. J., \& Delaney, A. (1964). Spectrophotometric studies and analytical application of the protein error of some $\mathrm{pH}$ indicators. Proceedings of the Australasian Association of Clinical Biochemists, 1, 64-67.

Beutler, E. (1963). Improved method for the determination of blood glutathione. Journal of Laboratory and Clinical Medicine, 61, 882-888.

Bieri, J. G., Tolliver, T. J., \& Catignani, G. L. (1979). Simultaneous determination of a-tocopherol and retinol in plasma or red cells by high pressure liquid chromatography. The American Journal of Clinical Nutrition, 32(10), 2143-2149.

Boden, G. (2011). 450besity, insulin resistance and free fatty acids. Current Opinion in Endocrinology, Diabetes, and Obesity, 18(2), 139-143.

Bonjour, J. P., Kohrt, W., Levasseur, R., Warren, M., Whiting, S., \& Kraenzlin, M. (2014). Biochemical markers for assessment of calcium economy and bone metabolism: Application in clinical trials from pharmaceutical agents to nutritional products. Nutrition Research Reviews, 27(2), 252-267.

Burtis, C. A., Ashwood, E. R., \& Bruns, D. E. (2012). Tietz textbook of clinical chemistry and molecular diagnostics-e-book. In Elsevier Health Sciences.

Cha, J. H., Yu, Q. M., \& Seo, J. S. (2016). Vitamin A supplementation modifies the antioxidant system in rats. Nutrition Research and Practice, 10(1), 26-32.

Cheung, R., Ng, T., Wong, J., \& Chan, W. (2015). Chitosan: An update on potential biomedical and pharmaceutical applications. Marine Drugs, 13(8), 5156-5186.

Chien, M. Y., Ku, Y. H., Chang, J. M., Yang, C. M., \& Chen, C. H. (2016). Effects of herbal mixture extracts on obesity in rats fed a high-fat diet. Journal of Food and Drug Analysis, 24(3), 594-601.

Choi, C., Nam, J. P., \& Nah, J. W. (2016). Application of chitosan and chitosan derivatives as biomaterials. Journal of Industrial and Engineering Chemistry, 33, 1-10.

Cui, B., Yu, Y., Yuan, W., Zhou, W., Zhou, X., \& Zhang, P. (2015). Variations in protein concentration and albumin/globulin ratio of whole unstimulated saliva obtained from healthy people and patients with chronic periodontitis. Journal of Stomatology, 33(4), 339-342.

Delamater, A. M., Pulgaron, E. R., \& Daigre, A. (2013). Obesity in adolescence. In Handbook of Adolescent Health Psychology, (pp. 597-618). New York: Springer.

Doumas, B. T. (1975). Standards for total serum protein assays-A collaborative study. Clinical Chemistry, 21(8), 1159-1166.

Eastep, J., \& Chen, G. (2015). The relationships of high-fat diet and metabolism of lipophilic vitamins. Integrative Food, Nutrition and Metabolism, 2(3), 174-179.

Fonseca-Alaniz, M. H., Takada, J., Alonso-Vale, M. I., \& Lima, F. B. (2007). Adipose tissue as an endocrine organ: From theory to practice. Jornal de Pediatria, 83(5), S192-S203.

Frommelt, L., Bielohuby, M., Stoehr, B. J., Menhofer, D., Bidlingmaier, M., \& Kienzle, E. (2014). Effects of low-carbohydrate, high-fat diets on apparent digestibility of minerals and trace elements in rats. Nutrition, 30(7-8), 869-875.

Haggag, M. S., Elsanhoty, R. M., \& Ramadan, M. F. (2014). Impact of dietary oils and fats on lipid peroxidation in liver and blood of albino rats. Asian Pacific Journal of Tropical Biomedicine, 4(1), 52-58.

He, Y. H., Song, Y., Liao, X. L., Wang, L., Li, G., Li, Y., \& Sun, C. H. (2011). The calcium-sensing receptor affects fat accumulation via effects on antilipolytic pathways in adipose tissue of rats fed low-calcium diets-3. The Journal of Nutrition, 141(11), 1938-1946.

Kerch, G. (2015). The potential of chitosan and its derivatives in prevention and treatment of age-related diseases. Marine Drugs, 13(4), 2158-2182.

Kessler, G., \& Wolfman, M. (1964). An automated procedure for the simultaneous determination of calcium and phosphorus. Clinical Chemistry, 10, 686-703.

Kumirska, J., Czerwicka, M., Kaczyński, Z., Bychowska, A., Brzozowski, K., Thöming, J. , \& Stepnowski, P. (2010). Application of spectroscopic methods for structural analysis of chitin and chitosan. Marine Drugs, 8(5), 1567-1636.

Mahassni, S. H., \& Al-Shaikh, N. A. (2013). Effects of vitamin A overdose on the immune system in rats. International Journal of Pharma Medicine and Biological Sciences, 2(4), 80-91.

Marseglia, L., Manti, S., D’Angelo, G., Nicotera, A., Parisi, E., Di Rosa, G., ... Arrigo, T. (2015). Oxidative stress in obesity: A critical component in human diseases. International Journal of Molecular Sciences, 16(1), 378-400.

Melhorn, S. J., Krause, E. G., Scott, K. A., Mooney, M. R., Johnson, J. D., Woods, S. C., \& Sakai, R. R. (2010). Acute exposure to a high-fat diet alters meal patterns and body composition. Physiology \& Behavior, 99(1), 33-39.

Mhurchu, C. N., Dunshea-Mooij, C., Bennett, D., \& Rodgers, A. (2005). Effect of chitosan on weight loss in overweight and obese individuals: A systematic review of randomized controlled trials. Obesity Reviews, 6(1), 35-42.

Muxika, A., Etxabide, A., Uranga, J., Guerrero, P., \& De La Caba, K. (2017). Chitosan as a bioactive polymer: Processing, properties and applications. International Journal of Biological Macromolecules, 105, 1358-1368.

Myles, I. A. (2014). Fast food fever: reviewing the impacts of the Western diet on immunity. Nutrition Journal, 13, 61. https://doi.org/10.1186/1475-2891-13-61.

Mythili, S., \& Malathi, N. (2015). Diagnostic markers of acute myocardial infraction. Biomedical Reports, 3(6), 743-748.

Nauck, M., März, W., Jarausch, J., Cobbaert, C., Sägers, A., Bernard, D., ... von Eckardstein, A. (1997). Multicenter evaluation of a homogeneous assay for HDLcholesterol without sample pretreatment. Clinical Chemistry, 43(9), 1622-1629.

Niki, E., \& Traber, M. G. (2012). Vitamin E history. Annals Nutrition Metabolism, 61 , 207-212.

Nobre, J. L., Lisboa, P. C., Santos-Silva, A. P., Lima, N. S., Manhães, A. C., NogueiraNeto, J. F., ... de Oliveira, E. (2011). Calcium supplementation reverts central adiposity, leptin, and insulin resistance in adult offspring programed by neonatal nicotine exposure. Journal of Endocrinology, 210(3), 349-359.

Patrulea, V., Ostafe, V., Borchard, G., \& Jordan, O. (2015). Chitosan as a starting material for wound healing applications. European Journal of Pharmaceutics and Biopharmaceutics, 97, 417-426.

Razali, N. M., \& Wah, Y. B. (2011). Power comparisons of shapiro-wilk, kolmogorovsmirnov, lilliefors and Anderson-darling tests. Journal of Statistical Modeling and Analytics, 2(1), 21-33.

Reeves, P. G., Nielsen, F. H., \& Fahey Jr., G. C. (1993). AlN-93 purified diets for laboratory rodents: Final report of the American Institute of Nutrition ad hoc writing committee on the reformulation of the AIN-76A rodent diet. Journal of Nutrition, 123(11), 1939-1951.

Rizvi, S., Raza, S. T., Ahmed, F., Ahmad, A., Abbas, S., \& Mahdi, F. (2014). The role of vitamin $\mathrm{E}$ in human health and some diseases. Sultan Qaboos University Medical Journal, 14(2), e157-e165.

Rodrigues, M. R., e Silva, A. D. S., \& Lacerda, F. V. (2012). The chitosan as dietary fiber: An in vitro comparative study of interactions with drug and nutritional substances. In The complex world of polysaccharides, (pp. 603-616). Rijeka: InTech. https://doi.org/10.5772/48311.

Sayed, A. A., Ali, A. A., \& Mohamed, H. R. (2018). Fertility enhancing efficacy of Cicer arietinum in male albino mice. Cellular and Molecular Biology, 64(4), 29-38.

Schumann, G., Bonora, R., Ceriotti, F., Férard, G., Ferrero, C. A., Franck, P. F., ... Kessner, A. (2002a). IFCC primary reference procedures for the measurement of catalytic activity concentrations of enzymes at 37 C. Part 4. Reference procedure for the measurement of catalytic concentration of alanine aminotransferase. Clinical Chemistry and Laboratory Medicine, 40(7), 718-724.

Schumann, G., Bonora, R., Ceriotti, F., Férard, G., Ferrero, C. A., Franck, P. F.. ... Kessner, A. (2002b). IFCC primary reference procedures for the measurement of catalytic activity concentrations of enzymes at 37 C. Part 5. Reference procedure for the measurement of catalytic concentration of aspartate aminotransferase. Clinical Chemistry and Laboratory Medicine, 40(7), 725-733.

Shen, X. H., Tang, Q. Y., Huang, J., \& Cai, W. (2010). Vitamin E regulates adipocytokine expression in a rat model of dietary-induced obesity. Experimental Biology and Medicine, 235(1), 47-51.

Snel, M., Jonker, J. T., Schoones, J., Lamb, H., De Roos, A., Pijl, H., ... Jazet, I. M. (2012). Ectopic fat and insulin resistance: Pathophysiology and effect of diet 
and lifestyle interventions. International Journal of Endocrinology, 2012, 983814. https://doi.org/10.1155/2012/983814.

Sohet, F. M., Neyrinck, A. M., Dewulf, E. M., Bindels, L. B., Portois, L., Malaisse, W. J., ... Delzenne, N. M. (2009). Lipid peroxidation is not a prerequisite for the development of obesity and diabetes in highfat-fed mice. British Journal of Nutrition, 102, 462-469.

Sullivan, D. R., Kruijswijk, Z., West, C. E., Kohlmeier, M., \& Katan, M. B. (1985). Determination of serum triglycerides by an accurate enzymatic method not affected by free glycerol. Clinical Chemistry, 31(7), 1227-1228.

Suvarna, K. S., Layton, C., \& Bancroft, J. D. (Eds.). (2018). Bancroft's theory and practice of histological techniques e-book. Elsevier Health Sciences.

Tabacco, A., Meiattini, F., Moda, E., \& Tarli, P. (1979). Simplified enzymic/colorimetric serum urea nitrogen determination. Clinical Chemistry, 25(2), 336-337.

Tietz, N. W., Rinker, A. D., \& Shaw, L. M. (1983). IFCC methods for the measurement of catalytic concentration of enzymes Part 5. IFCC method for alkaline phosphatase (orthophosphoric-monoester phosphohydrolase, alkaline optimum, EC 3.1. 3.1). Journal of Clinical Chemistry and Clinical Biochemistry, 21(11), 731-748.

Toora, B. D., \& Rajagopal, G. (2002). Measurement of creatinine by Jaffe's reaction--determination of concentration of sodium hydroxide required for maximum color development in standard, urine and protein free filtrate of serum. Indian Journal of Experimental Biology, 40(3), 352-354

Uchiyama, M., \& Mihara, M. (1978). Determination of malonaldehyde precursor in tissues by thiobarbituric acid test. Analytical Biochemistry, 86(1), 271-278.

Walsh, A. M., Sweeney, T., Bahar, B., \& O'Doherty, J. V. (2013). Multi-functional roles of chitosan as a potential protective agent against obesity. PLoS One, 8(1), e53828. https://doi.org/10.1371/journal.pone.0053828.

Wang, Z. F., Wang, M. Y., Yu, D. H., Zhao, Y., Xu, H. M., Zhong, S., ... Li, H. J. (2018). Therapeutic effect of chitosan on $\mathrm{CCl}$-induced hepatic fibrosis in rats. Molecular Medicine Reports, 18(3), 3211-3218.

Wieland, H., \& Seidel, D. (1983). A simple specific method for precipitation of low density lipoproteins. Journal of Lipid Research, 24(7), 904-909.

Winterbourn, C. C., Hawkins, R. E., Brian, M., \& Carrell, R. W. (1975). The estimation of red cell superoxide dismutase activity. The Journal of Laboratory and Clinical Medicine, 85(2), 337-341.

Zingg, J. M. (2007). Vitamin E: An overview of major research directions. Molecular Aspects of Medicine, 28(5-6), 400-422.

\section{Submit your manuscript to a SpringerOpen ${ }^{\circ}$ journal and benefit from:}

- Convenient online submission

- Rigorous peer review

- Open access: articles freely available online

High visibility within the field

- Retaining the copyright to your article

Submit your next manuscript at $\boldsymbol{\nabla}$ springeropen.com 